\title{
Bacteriological and Molecular Detection with Antimicrobial Resistance Pattern of Major Streptococcus spp. Isolated from Bovine Mastitis
}

\author{
B. B. Javia ${ }^{1^{*}}$, B. S. Mathapati ${ }^{1}$, D. B. Barad ${ }^{1}$, S. N. Ghodasara ${ }^{1}$, H. H. Savsani ${ }^{2}$, \\ A. R. Bhadaniya ${ }^{3}$, D. T. Fefar ${ }^{3}$, U. D. Patel ${ }^{4}$ and S. H. Sindhi ${ }^{5}$
}

${ }^{1}$ Department of Veterinary Microbiology, ${ }^{2}$ Department of Animal Nutrition, ${ }^{3}$ Department of Veterinary Pathology, ${ }^{4}$ Department of Veterinary Pharmacology and toxicology, ${ }^{5}$ Department of Veterinary Public Health and Epidemiology, College of Veterinary Science and A. H., Junagadh Agricultural University, Junagadh, Gujarat, India

*Corresponding author

\section{A B S T R A C T}

\section{Keywords}

Bovine Mastitis, Major

Streptococcus spp., Molecular

Detection,

Antimicrobial

Resistance

\section{Article Info}

Accepted:

17 October 2020

Available Online:

10 November 2020
Mastitis in bovine cause various clinical consequence with much losses in milk quality. Inflammatory infection caused by various bacteria damage the mammary gland and sometimes leads irreversible damage to the udder tissue. Looking to above problem the current study was performed to know the prevalence of major Streptococcus spp. with its timely detection by molecular methods and its antimicrobial resistance patterns. Total 390 bovine milk samples (180 clinically mastitic and 210 from apparently healthy) were studied. Initially samples were screened for major Streptococcus spp. by conventional bacteriological methods of identification. The molecular detection of Streptococcus genus and its major species Viz; Streptococcus agalactiae, Streptococcus dysgalactiae and Streptococcus uberis was carried out by polymerase chain reaction by targeting $\mathrm{Tu}$ (tuf) gene, sip gene, $16 \mathrm{~S}$ rRNA gene and pau gene respectively. Based on these overall 16.67 per cent of prevalence was observed for Streptococci. Among the major species, prevalence of $S$. agalactiae, S. dysgalactiae and S. uberis were found 13.59, 2.31 and 0.77 per cent respectively. These isolates showed highest antimicrobial resistance against amoxicillin- sulbactam $(72.25 \%)$ followed by ceftriaxone $(66.19 \%)$ and oxytetracycline $(53.12 \%)$ while the gentamicin $(8.38 \%)$ were found least resistant.

\section{Introduction}

Dairying the major connected activity associated with agriculture has now grown to the industrial scale contributing to the livelihood of millions of farmers in the country. Many elements including poor quality housing, inadequate nutrition, poor management practices and intra mammary infection are mostly responsible for decreased the production as well changed in quality of milk. Intramammary bacterial infection by bacteria damages the mammary gland and cause mastitis in bovine. It happens in various forms like mild sub clinical as well as clinical forms. Subclinical mastitis (SCM) occur 
without any physical changes to milk and udder tissue but cause more financial losses to dairy industries (Shaheen et al., 2016). So far approximately over 200 microbial species, sub species and subtypes have been isolated from bovine mammary gland (Mallikarjunaswamy and Krishnamurthy, 1997) and identified as causative agents of bovine mastitis. From all the aetiologies about 95 per cent of the identified cases are caused by Streptococcus agalactiae, Staphylococcus aureus and Streptococcus dysgalactiae, Streptococcus uberis and Escherichia coli (Jain et al., 2012; Kandemir et al., 2013). These predominant Streptococcus spp. play very important role in causing bovine mastitis and usually require special care for its isolation and identification. Antibiotic resistance patterns of these bacteria are helpful in treating the cases with best available antibiotics. Molecular techniques of diagnosis are widely used nowadays to reduce time and labour involved in conventional approaches. So keeping in views this study was undertaken to know prevalence of major Streptococcus spp. as an etiological agents of bovine mastitis with conventional and molecular methods its antimicrobial resistance patterns.

\section{Materials and Methods}

The present study was carried out from bovine clinical mastitic milk samples brought at Teaching Veterinary Clinical Complex as well as milks samples collected from apparently health bovine livestock. The Media, chemicals and reagents used in this study were of analytical and molecular grade. During the study 390 bovine milk samples including 180 from clinical mastitis cases and 210 from apparently healthy bovine were subjected for investigation. The somatic cell count (SCC) value > 5,00,000 cells $/ \mathrm{mL}$ of milk (Hegde et al., 2013) was considered the milk/animal as subclinically mastitic/infected.
Accordingly, 72 samples with SCC value > $5,00,000$ cells $/ \mathrm{mL}$ along with 180 clinical samples were subjected for cultural isolation. So finally 252 milk samples were processed for primary cultural isolation of major Strepotococcus spp. as an etiological agent of bovine mastitis. Initially milk samples were enriched in Streptococcus selection broth, with 5-10 per cent $\mathrm{CO}_{2}$ tension for 6 hours (hr.) at $37^{\circ} \mathrm{C}$ and then streaked onto blood agar plates. The plates were incubated at $37^{\circ} \mathrm{C}$ for $48 \mathrm{hr}$. After reading haemolysis in patterns and colony morphology, the colonies were again streaked onto blood agar plates and incubated further at $37^{\circ} \mathrm{C}$ for $48 \mathrm{hr}$. to obtain pure culture.

Gram staining was performed as per standard protocol and the pure cultures were subjected for biochemical tests viz: Catalase test, Oxidase test, Esculin Hydrolysis test and Christie, Atkins, Munch-Petersen (CAMP) test (Collee et al., 2008, Sandholm et al., 1995).

The molecular detection of Streptococcus genus and major Streptococcus spp. Viz; Streptococcus agalactiae, Streptococcus dysgalactiae and Streptococcus uberis was carried out by polymerase chain reaction(PCR). The genomic DNA from bacterial isolates was extracted by column based method of purification by using Nucleo-pore gDNA Fungal/Bacterial Mini Kit (Genetix brand). The concentration and purity of the purified genomic DNA was measured by using $\mu$ Drop $^{\mathrm{TM}}$ Plate in $\mathrm{uDrop}$ plate reader (Thermo Scientific). Further, the purity of the DNA sample was checked by electrophoresis on 0.8 per cent of the agarose gel. All the oligonucleotide primers were synthesized and obtained from Eurofins India, Bangore.

The Genus specific primers targeting the elongation factor $\mathrm{Tu}$ (tuf) gene of Streptococci was used for amplification of 
Streptococcus genus specific sequence. The primers targeting the Surface immunogenic protein (sip) gene of $S$. agalactiae was used for amplification of $S$. agalactiae specific sequence.

The primers targeting $16 S$ rRNA gene of $S$. dysgalactiae was used for amplification of $S$. dysgalactiae species specific sequence while the primers targeting the Plasminogen activator gene (pau) gene of $S$. uberis was used for amplification of $S$. uberis specific sequence (Nithinprabhu et al., 2013, Preethirani et al., 2015). The details of the primer sequences and its product size are depicted in table 1.

The PCR was performed in final reaction volume of $25 \mu \mathrm{l}$ in thermal cycler (Verity, Applied Biosystems by life technology, Singapore). The compositions of reaction mixture was prepared by using12.5 ul of $2 \mathrm{X}$ PCR mastermix (Fermentas), 1 ul of each forward and reverse primers (10 pmol/ul), 3 ul $(1 \mu \mathrm{g})$ of genomic DNA template in a total reaction volume of $25 \mu \mathrm{L}$ with addition of nuclease free water. The cycling conditions and annealing temperature optimized are shown in Table 2.The final PCR products were observed and visualized by agarose gel electrophoresis.

All the Streptococci isolates obtained were subjected to in vitro antibiotic sensitivity test as per the Kirby-Bauer method (Bauer et al., 1966) with commercially available discs(Table 3) in market on Mueller Hinton Agar medium (Himedia Lab.) with 5 per cent sheep blood.

The in-house reference strain previously characterized as $S$. dysgalactiae and $S$. agalactiae along with Streptococcus uberis (ATCC 700407) were used in this study as positive reference cultures. During the study Staphylococcus aureus (ATCC 43300) and
Escherichia coli (MTCC 722) were used as negative controls.

\section{Results and Discussion}

Bovine mastitis is the single most important factor contributing to the economic losses to the dairy industry, resulting in reduction in milk yield and quality of the milk. Out of the total 390 sample included in this study, 210 milk samples collected from apparently healthy bovine were subjected for SCC. A result of the SCC of 210 milk samples collected from bovine revealed overall 34.29 per cent (72/210) incidence of SCM. These 72 samples along with another 180 samples collected from clinical mastitis cases of bovine were included for cultural isolation predominant Streptococcus spp. In the cultural isolation, 235 samples were found positive for at least one species of bacteria. The isolated bacteria were identified up to genus level based on colony characteristics of individual primary isolate. The minute, dew drop colonies on blood agar (Figure 1) and Gram positive cocci in chain was primarily considered as Streptococcus spp. Further, these isolates were subjected to biochemical tests viz; catalase, oxidase, esculin hydrolysis and CAMP test. Accordingly 16.67 per cent (65/390) prevalence was observed for major Streptococcus spp. All the Streptococci isolates were negative for catalase and oxidase. Variability in biochemical profile was observed among different species. The overall and species wise prevalence of predominant Streptococcus species are highlighted in table 4.

Genus specific confirmation of the Streptococcus isolates was done by using primers targeting tuf gene. All the 65 major Streptococcal isolates yielded 110 bp amplicon. The reference cultures $S$. uberis (ATCC 700407) used as positive control also amplified similar size product while E. coli 
(MTCC 722) used as negative controls did not amplify the target gene (Figure 2).

Species specific sip gene of $S$. agalactiae, $16 S$ $r R N A$ of $S$. dysgalactiae and pau gene of $S$. uberis were targeted by the primer previously designed by Nithinprabhu et al., 2013. Out of total 65 isolates of Streptococcus spp., 53 isolates were amplified the sip gene specific 266bp amplicon (Figure 3) while 9 and 6 isolates amplified $16 \mathrm{~S} r R N A$ and pau gene specific 549bp (Figure 4) and 439bp (Figure 5) amplicon respectively. The respective amplification was also seen in the reference cultures $S$. agalactiae, S. dysgalactiae and
S.uberis (ATCC 700407) which were used as positive controls. Staphylococcus aureus (ATCC 43300) was used as negative controls and did not amplify the target gene.

Different level of antimicrobial-resistance were observed in Major Streptococcus spp. based on antibiotic susceptibility test. Here high level of antibiotic resistance was observed for amoxicillin- sulbactam (72.25\%), ceftriaxone (66.19\%) and oxytetracycline $(53.12 \%)$. These isolates were less resistance to levofloxacin $(10.14 \%)$ and gentamicin $(8.38 \%$ ) (Figure 6).

Table.1 The details of the primer sequences and its product size

\begin{tabular}{|c|c|c|c|c|}
\hline $\begin{array}{c}\text { Targeted } \\
\text { Genus/Species }\end{array}$ & Primer sequence (5'- 3') & $\begin{array}{c}\text { Target } \\
\text { gene }\end{array}$ & $\begin{array}{l}\text { Product } \\
\text { size }\end{array}$ & Reference \\
\hline \multirow[t]{2}{*}{ Streptococcus } & CAACTTGACGAAGGTCCTGCA & \multirow[t]{2}{*}{ tuf } & \multirow[t]{2}{*}{$110 \mathrm{bp}$} & \multirow{8}{*}{$\begin{array}{l}\text { Nithinprabhu } \\
\text { et al., 2010, } \\
2013, \\
\text { Preethirani et } \\
\text { al., } 2015\end{array}$} \\
\hline & TGGGTTGATTGAACCTGGTTTA & & & \\
\hline \multirow[t]{2}{*}{ S. agalactiae } & CTATTGACATCGACAATGGCAGC & \multirow[t]{2}{*}{ sip } & \multirow[t]{2}{*}{$266 \mathrm{bp}$} & \\
\hline & GTTACTGTCAGTGTTGTCTCAGGA & & & \\
\hline \multirow[b]{2}{*}{ S. dysgalactiae } & GGAGTGGAAAATCCACCAT & \multirow{2}{*}{$\begin{array}{c}16 S \\
r R N A\end{array}$} & \multirow[t]{2}{*}{$549 \mathrm{bp}$} & \\
\hline & CGGTCAGGAGGATGTCAAGAC & & & \\
\hline \multirow[b]{2}{*}{ S. uberis } & TGCTACTCAACCATCAAAGGTTGC & \multirow[t]{2}{*}{ pau } & \multirow[t]{2}{*}{$439 \mathrm{bp}$} & \\
\hline & TAGCAGTCTCAGTAGGATGAGTGA & & & \\
\hline
\end{tabular}

Table. 2 The cycling conditions and annealing temperature used in PCR

\begin{tabular}{|c|c|c|c|c|}
\hline \multicolumn{5}{|c|}{ Cycling conditions for Genus Streptococcus- Tuf gene } \\
\hline $\begin{array}{c}\text { Initial } \\
\text { denaturation }\end{array}$ & Denaturation & Annealing & Extension & Final extension \\
\hline \multirow{2}{*}{$\begin{array}{l}95^{\circ} \mathrm{C} \text { for } \\
5 \mathrm{~min}\end{array}$} & $94^{\circ} \mathrm{C}$ for $30 \mathrm{sec}$ & $50^{\circ} \mathrm{C}$ for $45 \mathrm{sec}$ & $72^{\circ} \mathrm{C}$ for $45 \mathrm{sec}$ & $72^{\circ} \mathrm{C}$ for $10 \mathrm{~min}$ \\
\hline & \multicolumn{3}{|c|}{ Repeated for 35 cycles } & \\
\hline \multicolumn{5}{|c|}{ Cycling conditions for S. agalactiae-sip gene } \\
\hline \multirow{2}{*}{$\begin{array}{l}94^{\circ} \mathrm{C} \text { for } \\
5 \mathrm{~min}\end{array}$} & $94^{\circ} \mathrm{C}$ for $30 \mathrm{sec}$ & $53^{\circ} \mathrm{C}$ for $45 \mathrm{sec}$ & $72^{\circ} \mathrm{C}$ for $45 \mathrm{sec}$ & \multirow[t]{2}{*}{$72^{\circ} \mathrm{C}$ for $10 \mathrm{~min}$} \\
\hline & \multicolumn{3}{|c|}{ Repeated for 40 cycles } & \\
\hline \multicolumn{5}{|c|}{ Cycling conditions for $S$. dysgalactiae $-16 S$ rRNA gene } \\
\hline \multirow{2}{*}{$\begin{array}{l}94^{\circ} \mathrm{C} \text { for } \\
5 \mathrm{~min}\end{array}$} & $94^{\circ} \mathrm{C}$ for $30 \mathrm{sec}$ & $51^{\circ} \mathrm{C}$ for $45 \mathrm{sec}$ & $72^{\circ} \mathrm{C}$ for $45 \mathrm{sec}$ & $72^{\circ} \mathrm{C}$ for $10 \mathrm{~min}$ \\
\hline & \multicolumn{3}{|c|}{ Repeated for 35 cycles } & \\
\hline \multicolumn{5}{|c|}{ Cycling conditions for S. uberis - paugene } \\
\hline \multirow{2}{*}{$\begin{array}{l}94^{\circ} \mathrm{C} \text { for } \\
5 \mathrm{~min}\end{array}$} & $94^{\circ} \mathrm{C}$ for $30 \mathrm{sec}$ & $55^{\circ} \mathrm{C}$ for $45 \mathrm{sec}$ & $72^{\circ} \mathrm{C}$ for $45 \mathrm{sec}$ & \multirow[t]{2}{*}{$72^{\circ} \mathrm{C}$ for $10 \mathrm{~min}$} \\
\hline & \multicolumn{3}{|c|}{ Repeated for 38 cycles } & \\
\hline
\end{tabular}


Table.3 Antimicrobial disc used during the study

\begin{tabular}{|l|c|}
\hline $\begin{array}{l}\text { Name of antibiotic with its } \\
\text { Concentration }\end{array}$ & $\begin{array}{c}\text { Break point to declare } \\
\text { resistance }\end{array}$ \\
\hline Amoxicillin/Salbactum(30/15 $\boldsymbol{\mu g})$ & $31 \mathrm{~mm}$ \\
\hline Ceftriaxone $(\mathbf{3 0} \boldsymbol{\mu g})$ & $24 \mathrm{~mm}$ \\
\hline Gentamicin $(\mathbf{1 0} \boldsymbol{\mu g})$ & $12 \mathrm{~mm}$ \\
\hline Levofloxacin $(\mathbf{5} \boldsymbol{\mu g})$ & $13 \mathrm{~mm}$ \\
\hline Oxytetracycline $(\mathbf{3 0} \boldsymbol{\mu g})$ & $18 \mathrm{~mm}$ \\
\hline
\end{tabular}

Table.4 Prevalence of bovine mastitis by predominant Streptococcal species

\begin{tabular}{|l|c|c|c|}
\hline Bacteria & $\begin{array}{c}\text { Total no. of milk samples } \\
\text { screened }\end{array}$ & $\begin{array}{c}\text { No. of positive } \\
\text { samples }\end{array}$ & $\begin{array}{c}\text { Prevalence } \\
(\%)\end{array}$ \\
\hline S. agalactiae, & 390 & 53 & 13.59 \\
\hline S. dysgalactiae & & 9 & 2.31 \\
\hline S. uberis & & 3 & 0.77 \\
\hline $\begin{array}{l}\text { Overall Streptococcal } \\
\text { Species }\end{array}$ & & 65 & 16.67 \\
\hline
\end{tabular}

Fig.1 Streptococcus spp. on $5 \%$ blood agar after $48 \mathrm{hr}$ incubation at $37^{\circ} \mathrm{C}$

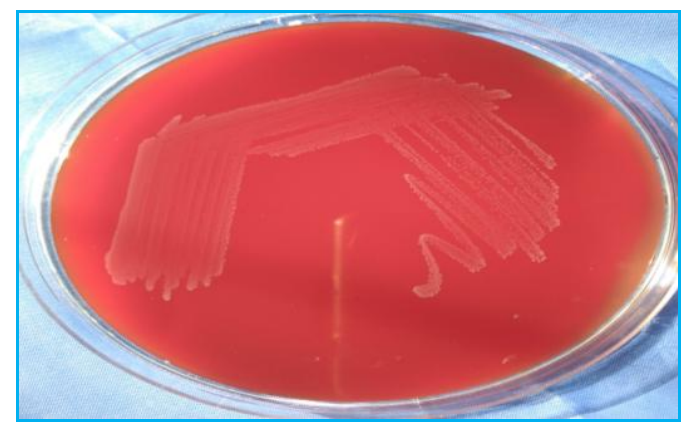

Fig.2 Genus specific PCR of Streptococcus spp. for tuf gene (110 bp)

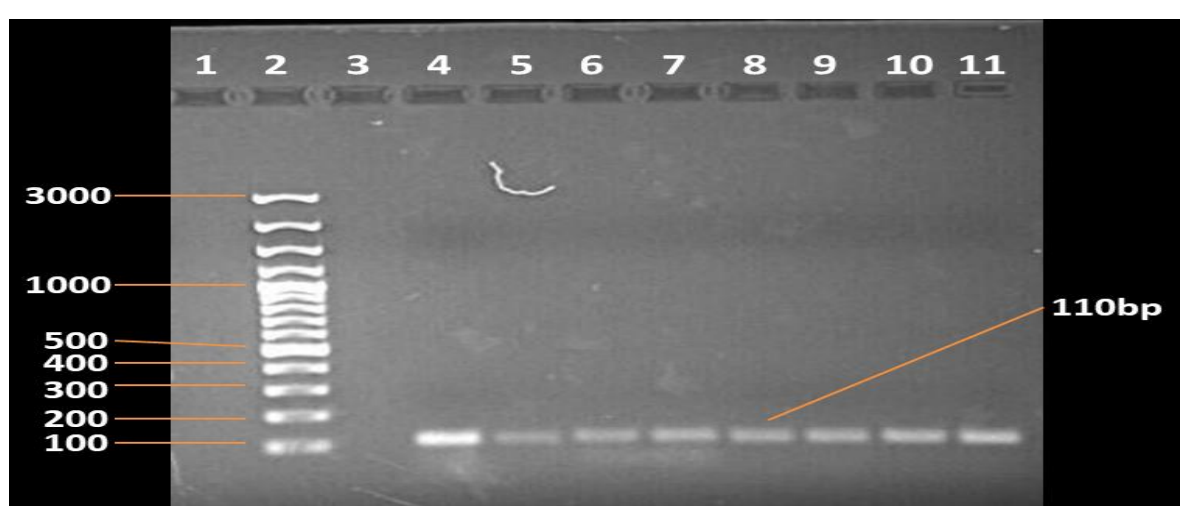

Lane 1: Negative template control, Lane 2: 100bp plus ladder, Lane 3: E. coli (MTCC 722) as negative control, Lane 4: S. uberis (ATCC 700407) as positive control, Lane 5 to 11: Streptococcus spp. isolates from bovine milk samples 
Fig.3 Species specific PCR of S. agalactiae for sip gene

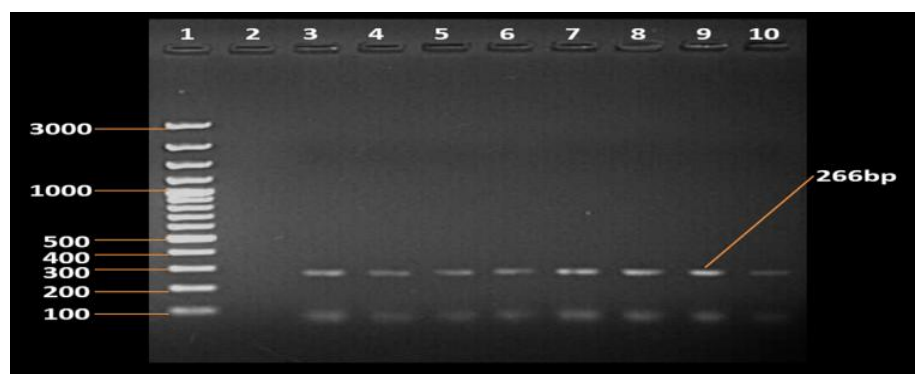

Lane 1: 100bp plus ladder, Lane 2: S. aureus (ATCC 43300) as negative control: Lane 3 S. agalactiae reference strain as positive control, Lane 4-10 S. agalactiae isolates from bovine milk samples

Fig.4 Species specific PCR of S. dysgalactiae for 16SrRNA gene

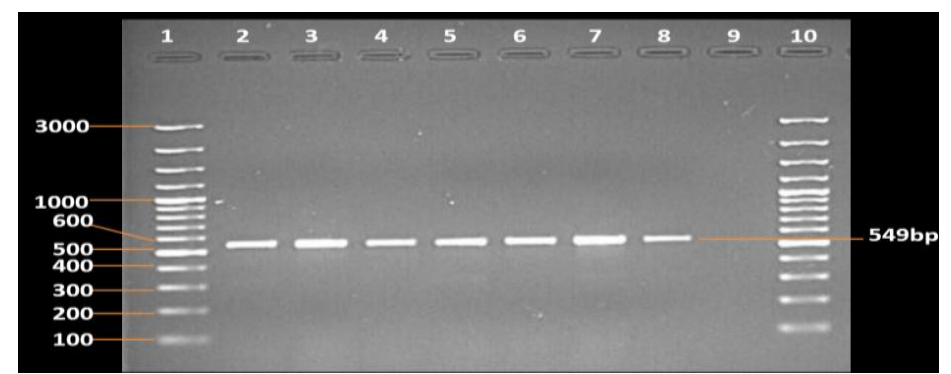

Lane 1: 100bp plus ladder, Lane 2: S. dysgalactiae as positive control, Lane 3 to 8: S. dysgalactiae isolates from bovine milk samples, Lane 9: S. aureus (ATCC 43300) as negative control, Lane 10: 100bp plus ladder

Fig.5 Species specific PCR of $S$. uberis for pau gene)

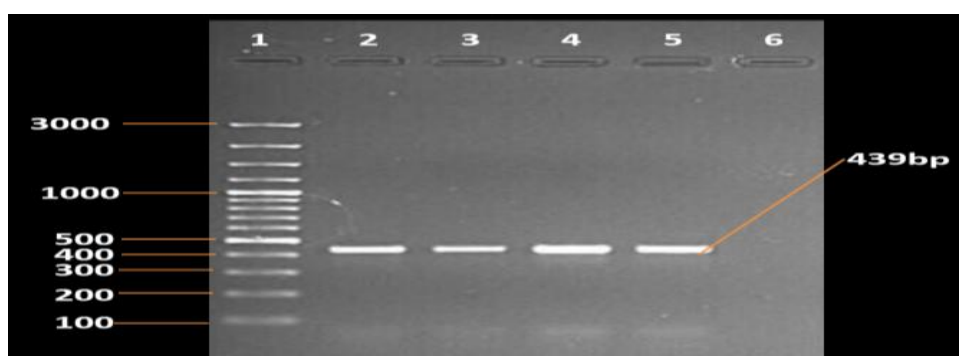

Lane 1: 100bp plus ladder, Lane 2: S. uberis (ATCC 700407) as positive control, Lane 3 to 5: S. uberis isolates from bovine milk samples, Lane 6: S. aureus (ATCC 43300) as negative control

Fig.6 Resistance patterns of Major Streptococcus spp.

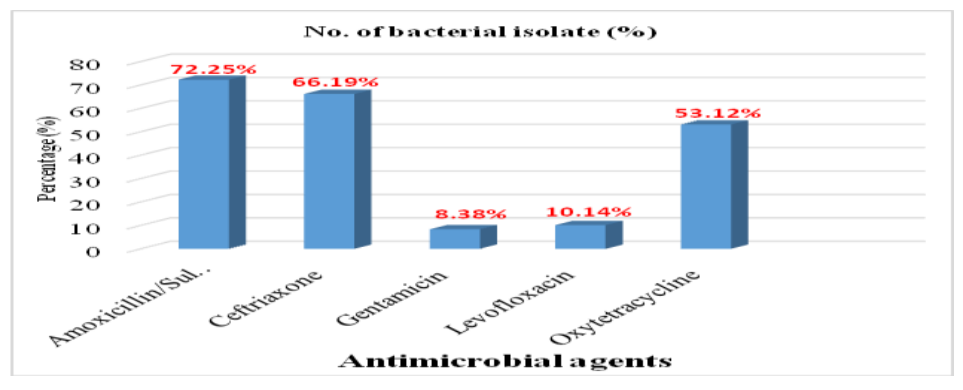


A result of the SCC of 210 milk samples collected from bovine revealed overall 34.29 per cent (72/210) incidence of SCM. These findings were also supported by Nithinprabhu (2010) and Hegde et al., (2013) who reported 47 per cent and 45 percent SCM respectively in bovine but it was in contrast to finding of Jena et al., (2015) who reported 74.55 per cent case SCM. Increased SCC as an indicator of intra mammary infection has been described previously (Hayakawa et al., 2000). In the present study 46.15 per cent (180/390) of milk samples collected from clinical mastitis cases were included for cultural isolation. This could be reason for observance high prevalence of bovine mastitis in current study. The comparable finding of high prevalence of bovine mastitis were also stated by Jena et al., (2015), Preethirani et al., (2015), Tesfaheywet and Gerema (2017).

The prevalence of mastitis caused by $S$. agalactiae, S. dysgalactiae and $S$. uberis was found $13.59 \%$ (53/390), $2.31 \%$ (9/390) and $0.77 \% \quad(3 / 390)$ respectively. Accordingly 16.67 per cent $(65 / 390)$ prevalence were observed for major Streptococci. Present study were very much in concordance with the earlier works who have isolated 18.51 per cent (Mohinikumari and Janakiramgupta, 2002), 14.01 per cent (Rajeev, 2006), 17.9 per cent (Feng-Li-Yang et al., 2011) and 18.1\% per cent (Preethirani et al., 2015) prevalence of Streptococci. These studies in general indicated the high prevalence of $S$. agalactiae among Streptococci isolated from bovine mastitis cases based on their conventional studies. In the present study variability observed in biochemical differentiation of major Streptococcal spp. were confirmed by amplification of species specific gene which was found more suitable for detection. Gonano and Winter, 2008, Hegde et al., 2013 also observed that a consistent biochemical differentiation of Streptococcus species was tough and conventional routine diagnostics have to be upgraded to give specific information on species level for creating farm specific mastitis prevention programs. Hence, these findings highlight the need to depend on molecular methods based on 16SrRNAgenefor accurate identification of Streptococci (Facklam, 2002). Quick nucleic acid amplification and detection tools are quickly transferring the traditional test which is based on phenotypic characteristic rather than its genotype. The PCR has increasingly been described as the latest gold standard for detecting mastitis pathogens by many scientists (Phuektes et al., 2001, Shome et al., 2011, Hegde et al., 2013, Javia et al., 2018, Ghodasara et al, 2018). Sequence analyses of conserved "housekeeping" genes such as the bacterial $16 S r R N A$ and other species specific are increasingly being used to identify bacterial species in clinical practice and scientific investigations (Petti et al., 2005).

Streptococcal infections in both humans and bovines are treated by administration of antibiotics. Penicillin was the drug of choice for treatment of both human and bovine $S$. agalactiae infections (Schrag et al., 2000). Antibiotic resistance against Amoxicillin/ Sulbactum was observed $72.25 \%$ in present study which may be due to extensive use of these antibiotics during treatment. Levofloxacin and Gentamicin has been found to be the most sensitive $89.86 \%$ and $91.62 \%$ respectively which was in accordance to some of the reports (Bhanot et al., 2012 and Ranjan et al., 2010). In this study, 53.12\% isolates were resistant to oxytetracycline, which is in contrast to Duarte et al., 2004 who observed $100 \%$ resistance to tetracycline. High degree of antimicrobial resistance suggests to improve judicious use of it for the treatment of bovine mastitis.

Bovine mastitis diagnosis and its treatment with most effective drug is an important factor for growth of animal husbandry sector 
and timely detection of subclinical mastitis by molecular methods is a need of coming days.

\section{References}

Bauer, A.W., Kirby, W.M.M., Sherris, J.C. and Toun, M. 1966. Antibiotic susceptibility testing using standard single disc diffusion method. American Journal of Clinical Pathology, 45: 493-496.

Bhanot, V., Chaudhri, S.S., Bisla, R.S. and Singh H. 2012. Retrospective study on prevalence and antibiogram of mastitis in cows and buffaloes of eastern Haryana. Indian Journal of Animal Research,46 (2): 160- 163.

Collee, J.G., Fraser, A.G., Marmion, B.P. and Simmons, D.K. (2008). In: Practical Medical Microbiology. $17^{\text {th }}$ Ed, Churchil Livingstone. New York, Edinburgh. London, p. 813-834.

Facklam, R. 2002. What happened to the streptococci: Overview of taxonomic and nomenclature changes. Clinical Microbiology Review, 15: 613-630.

Feng-li-Yang, Xiao-Shan Li, Bao-Xiang He, YuDan Du, Gong-He Li, Bin-Bin Yang and Hunang Qin-Hua. 2011. Bovine mastitis in subtropical dairy farms from 20052009. Journal of Animal and Veterinary Advance, 10(1): 68-72.

Ghodasara, S.N., Purohit, J.H., Mathapati, B.S., Barad, D.B., Javia, B.B., Kalaria, V.A., Patel A. and Bhanderi, B.B. 2018. Detection of virulence genes associated with Methicillin-resistant staphylococci from animal and Human clinical samples. Indian J. Comp. Microbiol. Immunol. Infect. Dis., Vol. 39 No. 1 (Jan-June): 2832.

Gonano, M. and Winter. P. 2008. Phenotypic and molecular identification of Streptococcal species isolated from milk of intra mammary infected Dairy cows in Austria. In: Proceedings of international conference on 'Mastitis control: from science to practice', The Hague, Netherlands, $30^{\text {th }}$ Sept $-2^{\text {nd }}$ Oct 2008, pp: 191-198.

Hayakawa, Y., Akagi, M., Hayashi, M.,
Shimango, T., Komae, H., Funaki, O., Kaidoh, T. and Takeuchi, S. 2000. Antibody response to toxic shock syndrome toxin-1 of Staphylococcus aureus in dairy cows. Veterinary Microbiology, 72: 321-327.

Hegde, R., Isloor, S., Prabhu, K.N., Shome, B.R., Rathnamma, D., Suryanarayana, V.V.S., Yatiraj, S., Prasad, C.R., Krishnaveni, N. and Sundareshan, S. 2013. Incidence of subclinical mastitis and prevalence of major mastitis pathogens in organized farms and unorganized sectors. Indian Journal of Microbiology, 53(3): 315-320.

Jain, B., Tiwari, A., Bhanderi, B.B. and Jhala, M.K. 2012. Antibiotic resistance and virulence genes in Streptococcus agalactiae isolated from cases of bovine subclinical mastitis. Veterinary Archive, 82: 423-432.

Javia, B.B., Purohit, J.H., Mathapati, B.S., Barad, D.B., Savsani, H.H., Ghodasara, S.N., Kalariya, V.A., Patel, U. D. and Nimavat, V.R. 2018. Molecular Detection and Antimicrobial Resistance Pattern of Staphylococci Isolated from Clinical and Subclinical Bovine Mastitis. The Indian Journal of Veterinary Sciences \& Biotechnology, Volume 14(1): 13-16,

Jena, B., Pagrut, N., Sahoo, A. and Ahmed, A. 2015. Subclinical bovine mastitis in rural, peri-urban and suburban regions of Jaipur district of Rajasthan, Journal of Animal Research, 5: 175-182.

Kandemir, F., Yuksel, M., Ozdemir, N. and Deveci, H. 2013: A different approach to diagnosis of subclinical mastitis: milk arginase activity. Veterinary Archive, 83: 603-610.

Mallikarjunaswamy, M.C. and Krishnamurthy, G.V. 1997. Antibiogram of bacterial pathogens isolated from bovine mastitis cases. Indian Veterinary Journal, 74(10): 885-887.

Mohinikumari, P. and Janakiramgupta, B., 2002. Diagnosis and therapy of subclinical mastitis in post parturient cows. Indian Veterinary Journal, 79: 89.

Nithinprabhu, K. 2010. Isolation, characterization and genetic diversity of Streptococcus species in subclinical bovine mastitis. 
M.V.Sc. Thesis, Karnataka Veterinary, Animal and Fisheries Sciences University, Bidar, India.

Nithinprabhu, K., Isloor, S., Hegde, R., Rathnamma, D., Veeregowda, B.M. and Narasimha Murthy, H.N. 2013. Development of polymerase chain reaction for detection of predominant Streptococcal isolates causing subclinical bovine mastitis. Indian Journal of Biotechnology, 12: 208-212.

Petti, C.A., Polage, C.R., Schreckenberger, P. 2005. The role of $16 \mathrm{~S}$ rRNA gene sequencing in identification of microorganisms mis identifed by conventional methods. Journal of Clinical Microbiology, 43: 6123-6125.

Phuektes, P., Mansell, P.D and Browning, G.F. 2001. Multiplex polymerase chain reaction assay for simultaneous detection of Staphylococcus aureus and I causes of bovine mastitis. Journal of Dairy Science, 84(5): 1140-1148.

Preethirani, P.L., ShrikrishnaIsloor., Sundareshan, S., Nuthanalakshmi, V., Deepthikiran, K., Sinha, A.Y., Rathnamma, D., Nithinprabhu, K., Sharada, R., Mukkur, T.K. and Hegde, N.R. 2015. Isolation, biochemical and molecular identification and in-vitro antimicrobial resistance patterns of bacteria isolated from bubaline subclinical mastitis in South India. PLOS ONE. 10(11):1-15.

Rajeev, N.K., 2006. Characterization of predominant bacteria from cases of bovinemastitis with special reference to genotyping of Staphylococcus aureus.M.V.Sc. thesis, Karnataka
Veterinary, Animal and Fisheries Sciences University, Bidar, India.

Ranjan, R., Gupta, M. K., Singh, S. and Kumar S. 2010 Current trend of drug sensitivity in bovine mastitis. Veterinary World, 3(1): 17-20.

Sandholm, G., Sommer, H. H. and Matsen. H., 1995. The relation of mastitis to rennet coagulability and curd strength of milk. Journal of Dairy Science, 18: 741-749.

Schrag, S.J., Zywicki, S., Farley, M.M., Reingold, A.L., Harrison, L.H., Lefkowitz, L.B., Hadler, J.L., Danila, R., Cieslak, P. R. and Schuchat A. 2000. Group B Streptococcal disease in the era of intrapartum antibiotic prophylaxis. The New England Journal of Medicine, 342: 15-20.

Shaheen, M., Tantary, H.A. and Nabi, S.U. 2016. A Treatise on bovine mastitis: disease and disease economics, etiological basis, risk factors, impact on human health, therapeutic management, prevention and control strategy. Journal of Advances in Dairy Research, 4: 150.

Shome, B.R., Das Mitra, S., Bhuvana, M, Krithiga, N., Velu, D., Shome, R., Isloor, S., Barbuddhe, S.B. and Rahman, H. 2011. Multipplex PCR assay for species identification of bovine mastitis pathogens. Journal of Applied Microbiology, 111(6): 1349-1356.

Tesfaheywet, Z. and Gerema, A. 2017. Prevalence and Bacterial Isolates of Mastitis in Dairy Farms in Selected Districts of Eastern Harrarghe Zone, Eastern Ethiopia. Journal of Veterinary Medicine, 2017: 1-6

\section{How to cite this article:}

Javia, B. B., B. S. Mathapati, D. B. Barad, S. N. Ghodasara, H. H. Savsani, A. R. Bhadaniya, D. T. Fefar, U. D. Patel and Sindhi, S. H. 2020. Bacteriological and Molecular Detection with Antimicrobial Resistance Pattern of Major Streptococcus spp. Isolated from Bovine Mastitis. Int.J.Curr.Microbiol.App.Sci. 9(11): 2443-2451. doi: https://doi.org/10.20546/ijcmas.2020.911.294 